\title{
Analisis Dinamika Kelompok pada Gapoktan Sekar Sari Desa Pangean Kecamatan Maduran Kabupaten Lamongan
}

\author{
ELISA SURTANTIN, NYOMAN SUTJIPTA, \\ NYOMAN PARINING \\ Program Studi Agribisnis, Fakultas Pertanian, Universitas Udayana \\ J1. PB. Sudirman Denpasar 80232 Bali \\ Email: elisasurtantin@gmail.com \\ nsutjiptacipta@yahoo.com
}

\begin{abstract}
Analysis of Group Dynamics at the Sekar Sari Farmers Group, Pangean Village, Maduran Sub-District of Lamongan Regency
\end{abstract}

Group dynamics is a branch of social science that studies the strengths that exist in the group, looking for the cause, and the effect on individuals and groups to act dynamically. Group dynamics can determine group behavior and group members' behavior to achieve common goals. The study aims to describe group dynamics at the Sekar Sari Farmers Group. The location of the research was determined purposively by the Sekar Sari group of Pangean farmers, Maduran Subdistrict, Lamongan Regency with the population of 131 people and the sample was 58 people based on the slovin formula and the data were analyzed by using descriptive analysis. The group dynamics of the Sekar Sari farmer group were viewed through a psychological approach that classified as high category with a percentage of $73.7 \%$. Group dynamics is seen through a sociological approach with very high category of $78.1 \%$. The influence of sociological approach to group dynamics on the Sekar Sari farmers group is higher than the psychological approach. The combined members of the Sekar Sari farmer group are expected to further enhance group cohesiveness, the organizers are expected to pay more attention to the farmer groups, and all members of the farmers group are expected to behave dynamically to achieve common goals.

Keywords: farmers group, group dynamics, psychological, sociological approach.

\section{Pendahuluan}

\subsection{Latar Belakang}

Gapoktan merupakan kumpulan kelompok tani yang bergabung menjadi satu dalam wilayah administratif (desa/kecamatan) yang dilakukan agar kelompok tani lebih berdaya guna dan berhasil guna dalam berusahatani sehingga menjadi organisasi petani yang kuat dan mandiri. Gapoktan Sekar Sari merupakan wadah belajar petani yang berada di Desa Pangean Kecamatan Maduran Kabupaten Lamongan. Gapoktan Sekar Sari merupakan gapoktan penerima dana bantuan PUAP dan merupakan gapoktan yang berhasil meraih juara satu tingkat kabupaten dalam pengelolaan air irigasi (lomba HIPPA AWARDS 2014) selain itu Gapoktan Sekar 
Sari juga telah memiliki banyak program kerja yang meliputi program program utama, program sosial maupun program kemitraan. Namun dengan pencapaian tersebut Gapoktan Sekar Sari masih mengalami ketidakaktifan anggota yang terjadi karena beberapa faktor antara lain keterbatasan kemampuan sumberdaya, rendahnya kesadaran anggota dalam mengembalikan pinjaman, serta keterbatasan waktu pengurus dan sebagian anggota dalam pengelolaan gapoktan. berdasarkan uraian tersebut penelitian ini mengkaji bagaimana dinamika kelompok pada Gapoktan Sekar Sari Desa Pangean Kecamatan Maduran Kabupaten Lamongan.

Setiap kelompok yang memiliki anggota belum tentu menjanjikan kinerja yang optimal, mengingat setiap anggota memiliki perbedaan karakter, kebiasaan, gaya hidup motivasi dan tujuan yang berbeda. Perbedaan tersebut dapat menyebabkan terjadinya konflik, semangat kerja menurun dan perpecahan. Dibutuhkan pemimpin untuk mengarahkan dan memadukan kekuatan-kekuatan yang ada di dalam suatu kelompok.

Analisis dinamika kelompok pada Gapoktan Sekar Sari sangat penting dilakukan untuk mengetahui pengaruh kekuatan-kekuatan yang ada di dalam gapokan baik itu dari segi psikologis maupun sosiologis serta mengetahui pendekatan mana yang lebih berpengaruh terhadap dinamika kelompok di Gapoktan Sekar Sari. Hal ini sebagai bahan acuan dan pembelajaran bagi Gapoktan Sekar Sari dalam pengembangan dan pengelolaan gapoktan sehingga bisa lebih berkembang dan sukses baik untuk saat ini maupun seterusnya.

\subsection{Tujuan}

Tujuan penelitian ini adalah mengetahui dinamika kelompok pada Gapoktan Sekar Sari Desa Pangean Kecamatan Maduran Kabupaten Lamongan.

\section{Metode Penelitian}

\subsection{Lokasi dan Waktu Penelitian}

Penelitian ini dilaksanakan di Gapoktan Sekar Sari Desa Pangean Kecamatan Maduran Kabuaten Lamongan. Penelitian dilaksanakan mulai dari bulan Maret 2017 sampai dengan April 2017. Pemilihan lokasi penelitian dilakukan secara sengaja berdasarkan pertimbangan yaitu (1) Gapoktan Sekar Sari merupakan salah satu gapoktan yang menjadi wahana belajar petani di Kecamatan Maduran; (2) Gapoktan Sekar Sari Pernah menjadi juara lomba HIPPA Awards Se- Kabupaten Lamongan; dan (3) Belum ada penelitian di Gapoktan Sekar Sari mengenai dinamika kelompok.

\subsection{Jenis Data dan Sumber Data}

Jenis data penelitian ini adalah kualitatif dan kuantitatif, sedangkan sumber data terdiri data primer dan data sekunder. 


\subsection{Metode Pengumpulan Data}

Metode yang digunakan dalam penelitian ini dikumpulkan dengan menggunakan teknik wawancara, wawancara mendalam, dan observasi.

\subsection{Responden Penelitian}

Populasi dalam penelitian ini adalah anggota kelompok Gapoktan Sekar Sari yang berjumlah 131 orang. Jumlah responden penelitian ini adalah 58 orang diperoleh dari perhitungan dengan menggunakan rumus slovin. Metode yang digunakan ialah simple random sampling.

\subsection{Variabel dan Analisis Data}

Variabel-variabel yang diukur dalam analisis ini adalah pendekatan psikologis dan pendekatan sosiologis. Pendekatan psikologis meliputi tujuan anggota kelompok; struktur kelompok; fungsi tugas kelompok; pembinaan dan pengembangan kelompok; kekompakan kelompok; suasana kelompok; tekanan kelompok; keefektifan kelompok; dan maksud tersembunyi. Pendekatan sosiologis meliputi tujuan kelompok; kepercayaaan; perasaan; norma; sanksi; kedudukan dan peranan; kekuasaan; jenjang sosial; fasilitas; tekanan dan tegangan. kedua variabel tersebut diukur menggunakan skala ordinal. Skor yang diberikan yaitu 1,2,3,4, dan 5. Skor 1 menyatakan sangat rendah, skor 2 menyatakan rendah, skor 3 menyatakan sedang, skor 4 menyatakan tinggi, skor 5 menyatakan sangat tinggi. Data yang telah dikumpulkan dan dianalisis melalui analisis deskriptif. Data pendekatan psikologis dan pendekatan sosiologis kemudian dilakukan perbandingan untuk mengetahui perbedaan pengaruh masing-masing pendekatan terhadap dinamika kelompok pada Gapoktan Sekar Sari.

\section{Hasil dan Pembahasan}

\subsection{Karakteristik Responden}

Karakteristik responden di Gapoktan Sekar Sari diperoleh dari data umur, pendidikan formal, luas lahan, pengalaman berusahatani, jumlah tanggungan rumah tangga.

Tabel 1.

Distribusi Responden Berdasarkan Karakteristik di Gapoktan Sekar Sari Tahun 2017

\begin{tabular}{cllcc}
\hline No & \multicolumn{1}{c}{ Karakteristik Responden } & \multicolumn{1}{c}{ Kategori } & $\begin{array}{r}\text { Jumlah } \\
\text { (orang) }\end{array}$ & $\%$ \\
\hline 1 & Umur & Sedang (>45-64 th) & 29 & 50,0 \\
2 & Pendidikan formal & Rendah (SD) & 18 & 31,0 \\
3 & Luas lahan & Sempit (20-113 are) & 37 & 63,8 \\
4 & Pengalaman berusahatani & Sebentar (17-19 th) & 18 & 31,0 \\
5 & Jumlah tanggungan rumah tangga & Sedikit (>2,2-3,4 orang $)$ & 19 & 32,8 \\
\hline
\end{tabular}

Sumber : Analisis data primer, 2017 
Berdasarkan Tabel 1 rata-rata sebagian besar responden pada penelitian ini berusia >45-64 tahun atau tergolong dalam kategori produktif. Menurut Badan Pusat Statistik (2012) dalam Sudartana (2016) berdasarkan komposisi penduduk, umur 014 tahun dianggap sebagai kelompok penduduk belum produktif, kelompok penduduk umur 15-66 tahun sebagai kelompok produktif dan umur 66 tahun keatas sebagai kelompok penduduk yang tidak produktif. Hal ini menunjukkan kemampuan petani cukup baik untuk tingkat produktivitas tenaga kerja dalam berusahtani. Hal ini sejalan dengan Isabella dkk, (2015) yang menyatakan bahwa petani dalam usia produktif akan memiliki tingkat produktivitas yang lebih tinggi dibandingkan petanipetani yang telah memasuki usia senja karena petani muda cenderung bersifat lebih progresif dalam proses transfer inovasi-inovasi baru, sehingga mampu mempercepat proses alih teknologi.

Bardasarkan pendidikannya, sebagian responden di Gapoktan Sekar Sari memiliki latar belakang pendidikan yang rendah. Hal ini menunjukkan bahwa sampai saat ini profesi petani banyak diminati oleh orang yang memiliki tingkat pendidikan rendah. Anggota Gapoktan Sekar Sari memerlukan wadah untuk belajar. Hasil penelitian ini sejalan dengan Saridewi (2010), yang menyatakan bahwa tingkat pendidikan seseorang dapat mengubah pengetahuan, sikap, dan ketrampilan yang baik, serta mendukung proses belajar dikemudian hari.

Sebagian besar responden di Gapoktan Sekar Sari merupakan petani lahan sempit hal ini menjadikan petani kurang bersemangat dalam berusahatani dan menjadi tidak fokus dalam memaksimalkan penggunaan lahan pertanian sebagai wadah interaksi karena pendapatan yang diperoleh sedikit. Akibatnya, sebagian petani lebih memilih mengambil pekerjaan sampingan yang dianggap mampu memenuhi kebutuhan rumah tangganya dibandingkan harus mengharapkan penghasilan dari berusahatani yang hasilnya sedikit. Hal ini sejalan dengan Rusidi (1989), bahwa petani dengan luas lahan usahatani yang sempit banyak menghadapi hambatan dalam peningkatan usahataninya, terutama jika dihadapkan dengan penggunaan inovasi atau teknologi baru, hal ini secara tidak langsung dapat mempengaruhi dinamika kelompok

Pengalaman usahatani yang dimiliki responden di Gapoktan Sekar Sari kurang mampu untuk meningkatkan kompetensi dalam berusahatani. Oleh sebab itu untuk meningkatkan kemampuan tersebut perlu adanya pembelajaran, binaan dan pengarahan agar petani mampu bertindak dinamis. Hal ini sejalan dengan Hadisapoetro, S. (1992), yang menyebutkan bahwa pengalaman berusahatani berhubungan erat dengan sikap dan keputusan yang terjadi pada diri petani. Dengan demikian semakin berpengalamannya petani dalam kegiatan usahatani dapat meningkatkan tingkat produktivitas hasil usaha, sehingga dapat meningkatkan pendapatan petani dan pada akhirnya lebih mudah untuk mengembalikan dana pinjaman.

Jumlah tanggungan rumah tangga yang dimiliki responden adalah sedikit maka responden akan lebih baik dalam menjalankan usahataninya dibandingkan dengan 
yang mempunyai tanggungan keluarga yang banyak. Adanya keluarga akan menjadi motivasi bagi anggota untuk lebih giat lagi berproduksi supaya memperoleh pendapatan yang cukup untuk memenuhi kebutuhan rumah tangga. Motivasi tersebut juga turut mendorong anggota dalam bertindak dinamis. Hasil penelitian ini sejalan dengan Arimbawa (2004) yang menyatakan bahwa jumlah tanggungan rumah tangga menjadi motivasi untuk lebih giat lagi dalam berproduksi dan melakukan belajar.

\subsection{Dinamika Kelompok Gapoktan Sekar Sari}

Dinamika kelompok adalah kekuatan-kekuatan yang ada dalam kelompok yang menentukan perilaku kelompok dan perilaku anggota kelompok untuk tercapainya tujuan. Kelompok yang dinamis ditandai dengan perilaku anggota dan interaksi yang baik di dalam kelompok maupun di luar kelompok secara efesien dan efektif mencapai tujuan (Sudarta, 2003). Dinamika kelompok yang dimaksud dalam penelitian ini yaitu menggunakan pendekatan psikologis dan pendekatan sosiologis. Menurut Mardikanto (1993) analisis dinamika kelompok dapat dilakukan dengan dua macam pendekatan, yaitu pendekatan psikologis dan sosiologis.

\subsubsection{Pendekatan psikologis}

Pendekatan psikologis merupakan pendekatan dinamika kelompok yang dilakukan terhadap segala sesuatu yang akan berpengaruh terhadap perilaku anggotaanggota kelompok dalam melaksanakan kegiatan demi tercapainya tujuan kelompok. Adapun Pendekatan psikologis memiliki beberapa unsur meliputi tujuan anggota kelompok; struktur kelompok; fungsi tugas kelompok; pembinaan dan pengembangan kelompok; kekompakan kelompok; suasana kelompok; tekanan kelompok; keefektifan kelompok; dan maksud tersembunyi.

Hasil penelitian tingkat kedinamisan kelompok ditinjau dari pendekatan psikologis menunjukkan bahwa dinamika kelompok pada Gapoktan Sekar Sari dalam kategori tinggi atau dinamis dengan pencapaian skor sebesar 73,7 \%.

Tabel 2.

Pencapaian Skor Indikator Pendekatan Psikologis Dinamika Kelompok pada Gapoktan Sekar Sari Tahun 2017

\begin{tabular}{|c|c|c|c|c|}
\hline No & Indikator Psikologis & Rata-rata & $\begin{array}{c}\text { Pencapaian skor } \\
(\%)\end{array}$ & Kategori \\
\hline 1 & Tujuan kelompok & 4,22 & 84,4 & Sangat tinggi \\
\hline 2 & Struktur kelompok & 3,90 & 77,9 & Tinggi \\
\hline 3 & Fungsi tugas & 3,84 & 76,8 & Tinggi \\
\hline 4 & $\begin{array}{l}\text { Pembinaan dan pengembangan } \\
\text { kelompok }\end{array}$ & 3,64 & 72,9 & Tinggi \\
\hline 5 & Kekompakan kelompok & 3,47 & 69,4 & Tinggi \\
\hline 6 & Suasana kelompok & 3,81 & 76,2 & Tinggi \\
\hline 7 & Tekanan kelompok & 3,55 & 70,9 & Tinggi \\
\hline 8 & Efektivitas kelompok & 3,69 & 73,8 & Tinggi \\
\hline \multirow[t]{2}{*}{9} & Maksud terselubung & 3,22 & 64,3 & Tinggi \\
\hline & Rata-rata & 3,70 & 73,7 & Tinggi \\
\hline
\end{tabular}

Sumber: Analisis data primer, 2017 
Berdasarkan Tabel 2 menunjukkan bahwa tujuan Gapoktan Sekar sari termasuk dalam kategori tinggi dengan total persentase sebesar 84,4\%. Gapoktan Sekar Sari telah memiliki tujuan yang jelas yang telah tertulis dalam AD/ART dan disepakati oleh semua anggota. Tujuan Gapoktan Sekar Sari telah sesuai dengan tujuan pribadi anggota yang ingin dicapai. Ini berarti bahwa jika banyak anggota yang memiliki kesesuaian tujuan maka anggota akan berusaha mewujudkan tujuan gapoktan agar tujuan pribadinya tercapai. Hasil penelitian ini sejalan dengan Suyatna (1982), yang menyatakan tujuan pribadi anggota kelompok dengan tujuan kelompok bisa bejalan searah sesuai dengan kepentingan bersama dan antara tujuan pribadi dan kelompok harus sejalan dengan tujuan kelompok, maka setiap anggota harus paham apa yang menjadi tujuan kelompok.

Struktur struktur kelompok Gapoktan Sekar Sari termasuk dalam kategori tinggi dengan total persentase sebesar $77,9 \%$. Pembagian tugas dan tanggung jawab yang ada di gapoktan sangat jelas secara tertulis, pengambilan keputusan dalam kelompok tani dilakukan oleh ketua dengan memperhatikan aspirasi pengurus dan anggota, selalu ada komunikasi antara pengurus dengan seluruh anggota, antara anggota yang satu dengan anggota lainnya dan dalam melakukan suatu kegiatan selalu dijelaskan serta didiskusikan dengan seluruh anggota kelompok. Struktur kelompok jelas, maka diharapkan akan tercipta interaksi yang intensif di antara anggota kelompok. Hal ini sesuai dengan pendapat Slamet (1978), bahwa yang terpenting dalam struktur kelompok adalah terciptanya interaksi yang intensif di antara anggota kelompok.

Fungsi tugas Gapoktan Sekar sari termasuk dalam kategori tinggi dengan total persentase sebesar 76,8\%. Anggota gapoktan menerima informasi dengan baik karena gapoktan selalu memberikan dan menjelaskan informasi dengan baik. Setiap melakukan kegiatan gapoktan selalu mendiskusikan kepada seluruh anggota. gapoktan mengajak seluruh anggota untuk terlibat aktif dalam kegiatan dan kelompok selalu terbuka kepada anggota apabila terjadi permasalahan dalam kegiatan.

Pembinaan dan pengembangan kelompok Gapoktan Sekar Sari termasuk dalam kategori tinggi dengan total persentase sebesar 72,9\%. Gapoktan sering mengadakan kegiatan maupun sosialisasi. Anggota gapoktan masih belum seluruhnya hadir dalam setiap kegiatan yang diselenggarakan. Adanya kontrol sosial menyebabkan anggota gapoktan selektif dalam melakukan berbagai tindakan.

Kekompakan kelompok Gapoktan Sekar Sari termasuk dalam kategori tinggi dengan total persentase sebesar 69,4\%. Kekompakan kelompok Gapoktan Sekar Sari terbina dengan baik. Pembentukan gapoktan didasarkan pada kebutuhan yang sama, dan kerukunan membuat saling mengenal dan akrab di antara anggota.

Suasana kelompok Gapoktan Sekar Sari termasuk dalam kategori tinggi dengan total persentase sebesar 74,8\%. Suasana kelompok di Gapoktan Sekar Sari 
terjalin baik dengan adanya kebebasan berpartisipasi, jalinan antar individu yang harmonis dan lingkungan fisik yang mempermudah pekerjaan.

Tekanan kelompok Gapoktan Sekar Sari termasuk dalam kategori tinggi dengan total persentase sebesar 70,9\%. Banyaknya harapan anggota kepada Gapoktan Sekar Sari dalam memenuhi kebutuhan usahatani menjadikan gapoktan harus selalu berusaha memenuhi kebutuhan para anggota. Hal ini menyebabkan Gapoktan memiliki tekanan/tegangan yang cukup tinggi.

Efektivitas Gapoktan Sekar Sari termasuk dalam kategori tinggi dengan persentase 73,8\%. Artinya Gapoktan Sekar Sari sudah efektif dalam mencapai tujuan yang akan dicapai. Hal ini dikarenakan mereka hanya mendapatkan kemudahan dalam bantuan modal tetapi belum maksimal dalam hal jaringan pemasaran. Efektifitas kelompok cukup baik, maka diharapkan dinamika kelompok yang terjalin juga baik. Hal ini dikarenakan keefektifan kelompok sangat penting, dimana efektifitas kelompok mempunyai pengaruh timbal balik dengan kedinamisan kelompok. Kelompok yang efektif akan mempunyai tingkat dinamika yang tinggi, sebaliknya kelompok yang dinamis akan efektif mencapai tujuan.

Maksud terselubung Gapoktan Sekar Sari termasuk dalam kategori tinggi dengan total persentase sebesar $64,3 \%$. Hal ini menunjukan bahwa tidak semua anggota mengetahui adanya maksud terselubung. Walaupun maksud terselubung mungkin ada dalam kelompok, tetapi maksud terselubung ini tidak begitu menimbulkan pengaruh yang sangat besar dalam kelompok

\subsubsection{Pendekatan sosiologis}

Pendekatan sosiologis merupakan dinamika kelompok yang dilakukan terhadap proses sosial kelompok. Adapun Pendekatan sosiologis memiliki beberapa unsur meliputi tujuan kelompok; kepercayaaan; perasaan; norma; sanksi; kedudukan dan peranan; kekuasaan; jenjang sosial; fasilitas; tekanan; dan tegangan.

Hasil penelitian tingkat kedinamisan kelompok melalui pendekatan sosiologis menunjukkan bahwa dinamika kelompok pada Gapoktan Sekar Sari berada dalam kategori tinggi dengan pencapaian skor sebesar 78,1\%. 
Tabel 3.

Pencapaian Skor Indikator Pendekatan Sosiologis Dinamika Kelompok pada Gapoktan Sekar Sari Tahun 2017

\begin{tabular}{clccc}
\hline \multirow{2}{*}{ No } & \multicolumn{1}{c}{ Indikator Sosiologis } & Rata-rata & $\begin{array}{c}\text { Pencapaian skor } \\
(\%)\end{array}$ & Kategori \\
\hline 1 & Tujuan kelompok & 4,04 & 80,8 & Sangat tinggi \\
2 & Kepercayaan kelompok & 3,91 & 78,3 & Tinggi \\
3 & Perasaan & 3,71 & 74,1 & Tinggi \\
4 & Norma & 3,97 & 79,3 & Tinggi \\
5 & Sanksi & 4,16 & 83,1 & Sangat tinggi \\
6 & Kedudukan dan peranan & 3,87 & 77,4 & Tinggi \\
7 & Kekuasaan & 3,57 & 71,5 & Tinggi \\
8 & Jenjang sosial & 3,51 & 70,2 & Tinggi \\
9 & Fasilitas & 4,16 & 83,2 & Sangat tinggi \\
10 & Tekanan dan tegangan & 4,14 & 82,8 & Sangat tinggi \\
\hline & & 3,90 & 78,1 & Tinggi \\
\hline
\end{tabular}

Sumber: Data Primer, 2017

Berdasarkan Tabel 3 menunjukkan bahwa tujuan Gapoktan Sekar Sari termasuk dalam kategori tinggi dengan persentase 80,8\%. Hal ini menunjukkan bahwa tujuan yang ada di Gapoktan Sekar Sari dicapai melalui interaksi yang bermafaat dengan diadakannya berbagai kegiatan untuk mengetahui gerak dari kelompok seperti sosialisasi, rapat anggota, kerja bakti dan kegiatan lainnya. Sehingga dengan adanya tujuan kelompok yang jelas akan menjadikan anggota mengetahui arah dari kegiatan kelompok.

Kepercayaan Gapoktan Sekar Sari termasuk dalam kategori tinggi. dengan persentase 78,3\%. Hal ini menunjukkan bahwa antar anggota gapoktan saling percaya satu sama lain meskipun masih ada beberapa yang kurang percaya. Seluruh anggota Gapoktan Sekar Sari mempercayai bahwa segala sesuatu yang terjadi adalah campur tangan dari tuhan yang maha kuasa. Adanya pegetahuan dan teknologi membantu mempermudah pekerjaan dan keberhasilan meningkatkan produktivitas.

Perasaan responden berada pada kategori tinggi dengan pencapaian skor sebesar 74,1\% artinya bahwa kesamaan tujuan anggota, latar belakang daerah dan adat budaya anggota gapoktan berpengaruh dalam mencapai tujuan kelompok sehingga selalu berusaha untuk bertindak dinamis.

Norma yang ada di Gapoktan Sekar Sari berada dalam kategori tinggi dengan persentase $79,3 \%$. Artinya bahwa norma gapoktan telah tertulis dengan jelas dan dipahami oleh anggota karena ketua gapoktan sering menjelaskan kepada anggota tentang norma yang ada dalam gapoktan.

Sanksi yang ada di Gapoktan Sekar Sari termasuk dalam kategori tinggi. Hal ini ditunjukkan dengan persentase $83,1 \%$. Hal ini menunjukkan bahwa peraturanperaturan yang ada telah memiliki sanksi yang jelas dan dipahami oleh anggota. Setiap anggota yang melanggar peraturan akan dihukum sesuai dengan tidakan yang dilanggar. 
Kedudukan dan peranan yang ada di Gapoktan Sekar Sari termasuk dalam kategori tinggi dengan persentase $76,1 \%$ hal ini menunjukkan bahwa anggota gapoktan memiliki hak dan kewajiban dalam melaksanakan tugas yang ada. Anggota memahami hak dan kewajiban yang akan dilaksanakan dalam gapoktan. Anggota gapoktan menjalankan hak dan kewajiban dengan baik.

Kekuasaan yang ada di Gapoktan Sekar Sari termasuk dalam kategori tinggi dengan presentase $71,5 \%$. Hal ini menunjukkan bahwa setiap keputusan yang ada di Gapoktan Sekar Sari ditentukan atas musyawarah dan mufakat dari semua anggota atau pengurus.

Jenjang sosial yang ada di Gapoktan Sekar Sari termasuk dalam kategori tinggi dengan persentase $70,2 \%$. Hal ini menunjukkan bahwa jenjang yang ada di Gapoktan Sekar Sari cukup jelas. sebagian besar anggota memahami tentang jenjang sosial. Jenjang sosial merupakan sumber motivasi bagi anggota kelompok untuk mencapai kemajuan.

Fasilitas yang ada di Gapoktan Sekar Sari termasuk dalam kategori tinggi dengan persentase $87,4 \%$. Hal ini menunjukkan bahwa gapoktan memiliki fasilitas yang cukup seperti tempat rapat, traktor, alat perontok padi, saluran irigasi yang baik, informasi yang cukup memadai, dan lain sebagainya. Fasilitas yang ada dapat digunakan dengan baik oleh anggota gapoktan. Fasilitas yang ada dipelihara dengan baik agar dapat digunakan dalam jangka waktu yang lama.

Tekanan dan tegangan yang ada di Gapoktan Sekar Sari termasuk dalam kategori tinggi dengan persentase $82,8 \%$. Hal ini menunjukkan bahwa tuntutan bagi gapoktan sangatlah besar mulai dari tuntutan untuk memenuhi kebutuhan anggota, tuntutan untuk mencapai tujuan gapoktan, dan tuntutan lainnya baik dari dalam maupun dari luar. Besar harapan anggota agar Gapoktan Sekar Sari dapat berkembang dengan baik dan menjadi Gapoktan yang mandiri dan menjamin kesejahteraan anggota.

\subsubsection{Perbedaan pengaruh pendekatan psikologis dan pendekatan sosiologis}

Perbedaan pengaruh antara variabel pendekatan psikologis dan variabel pendekatan sosiologis dapat diketahui dengan melakukan uji perbedaan data selisih kedua kelompok, menggunakan uji independent sample t-test. Hasil uji independent sample t-test perbedaan antara variabel pendekatan psikologis dan variabel pendekatan sosiologis dapat dilihat pada tabel 3.3 sebagai berikut. 


\section{Tabel 4.}

Hasil Uji Independent Sample t-test Perbedaan Hasil Dinamika Kelompok antara Variabel Pendekatan Psikologis dan Variabel Pendekatan Sosiologis

Independent Samples Test

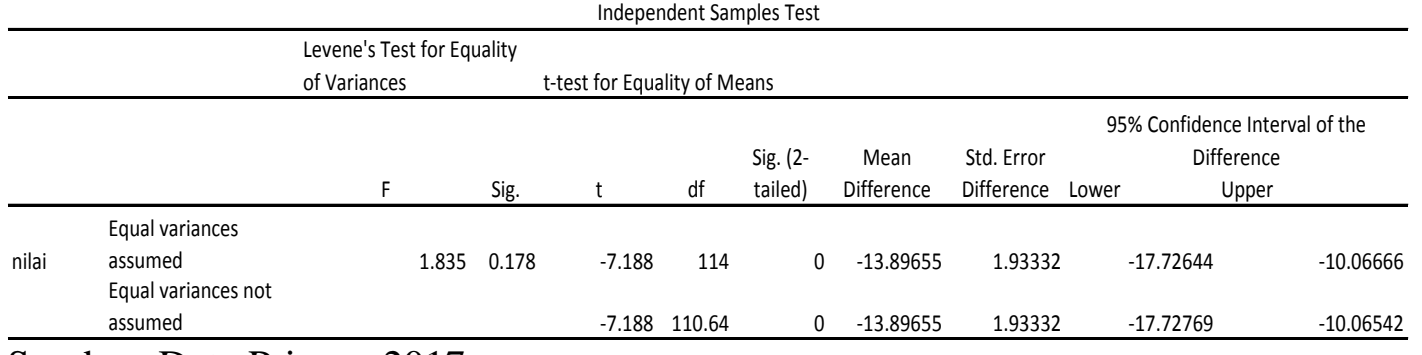

Sumber: Data Primer, 2017

Diketahui nilai t-hitung hasil penelitian dinamika kelompok variabel pendekatan psikologis dan pendekatan sosiologis adalah -7,188 dengan probabilitas (Sig.) 0,00. Probabilitas (Sig.) $0,000<0,1$ maka $\mathrm{H}_{0}$ ditolak. Artinya terdapat perbedaan yang signifikan antara hasil penelitian dinamika kelompok variabel pendekatan psikologis dan pendekatan sosiologis. Berdasarkan hasil pengolahan tersebut, maka dapat disimpulkan bahwa hasil penelitian dinamika kelompok variabel pendekatan psikologis dan pendekatan sosiologis memiliki perbedaan yang signifikan. Variabel pendekatan sosiologis lebih baik dibandingkan variabel pendekatan psikologis terhadap dinamika kelompok Gapoktan Sekar Sari. Hal ini dibuktikan dengan peningkatan hasil penelitian dinamika kelompok pada Gapoktan Sekar Sari variabel pendekatan sosiologis rata-ratanya lebih tinggi dibandingkan dengan variabel pendekatan psikologis.

\section{Simpulan dan saran}

\subsection{Simpulan}

Berdasarkan hasil analisis dan pembahasan tentang dinamika kelompok pada Gapoktan Sekar Sari, Desa Pangean, Kecamatan Maduran, Kabupaten Lamongan. dapat ditarik kesimpulan bahwa dinamika kelompok pada Gapoktan Sekar Sari berada pada kategori tinggi dengan hasil tinjauan pendekatan psikologis mencapaian skor sebesar $73,7 \%$ dalam kategori tinggi. Ditinjau dari segi sosiologis pencapaian skor sebesar 78,1\% dalam kategori tinggi juga, hal ini menunjukkan bahwa perilaku dan interaksi anggota Gapotan Sekar Sari sama-sama menunjukkan kedinamisan kelompok dan mendukung kemajuan gapoktan demi tercapainya tujuan bersama. Namun, meski dalam kategori tinggi anggota Gapoktan Sekar Sari masih belum sepenuhnya dapat bertindak sesuai dengan tujuan. Pengaruh pendekatan sosiologis lebih tinggi dibandingkan pendekatan psikologis hal ini menunjukkan bahwa antar anggota Gapoktan saling membutuhkan.

\subsection{Saran}

Berdasarkan hasil penelitian ini diharapkan agar angota Gapoktan Sekar Sari lebih meningkatkan kedinamisan gapoktan terutama pada indikator kekompakan 
kelompok. Pengurus gapoktan diharapkan untuk selalu menjaga hubungan kepada seluruh anggota gapoktan sehingga tetap dinamis. Dinamika kelompok diutamakan untuk merubah perilaku anggota agar mendukung tujuan gapoktan. meningkatkan rasa tanggung jawab dengan memberikan wewenang dan tanggung jawab, melibatkan anggota dalam pengambilan keputusan dan kegiatan, menghormati harkat dan martabat anggota sehingga menimbulkan sifat baik dan simpati anggota pada gapoktan dengan bekerja lebih baik.

\section{Ucapan Terimakasih}

Terimakasih kepada Ketua Gapoktan Sekar Sari dan seluruh responden Gapoktan Sekar Sari yang telah memberikan informasi dan segala bantuan dalam pelaksanaan penelitian dan penulisan e-journal ini. Smoga Bermanfaat sebagaimana mestinya.

\section{Daftar Pustaka}

Arimbawa, P. 2004. Peran Kelompok Untuk Meningkatkan Kemampuan Anggota Dalam Penerapan Inovasi Teknologi. Bogor: Institut Pertanian Bogor.

Hadisapoetro S. 1992. Usaha Pembinaan Usahatani Lahan Sempit. Departemen Ekonomi Pertanian. Fakultas Pertanian Universitas Gadjah Mada: Yogyakarta.

Isabella,Ulfa, Suwarto Suprapto. 2015. Analisis pengaruh kelembagaan lahan, lingkungan usahatani, dan faktor produksi pada usahatani padi Sawah di Kabupaten Caruban Jawa Timur. Surakarta: Universitas Sebelas Maret.

Mardikanto, totok. 1993. Penyuluhan Pembangunan Pertanian. Surakarta: Penerbit Sebelas Maret. University Press.

Rusidi. 1989. Dinamika Kelompok Tani Dalam Struktur Kekuasaan Masyarakat Desa Serta Pengaruhnya terhadap Perilaku Berusahatani Petani Berlahan Sempit dan Kekuatan Ikatan Patron Klien. Universitas Padjadjaran: Bandung.

Saridewi. 2010. Pengaruh Profesionalisme, Tingkat Pendidikan, dan Pengalaman Kerja Pada Kinerja Badan Pengawas Lembaga Pengkreditan Desa (Penelitian LPD di Kota Denpasar). Denpasar: Universitas Udayana.

Slamet, Margono. 1978. Kumpulan Bahan Bacaan Penyuluhan Pertanian. Edisi ke3. Institut Pertanian Bogor.

Sudarta, Wayan. 2004. Kelompok, Organisasi dan Kepemimpinan. Jurusan Sosial Ekonomi Pertanian, Fakultas Pertanian, Universitas Udayana. Denpasar.

Sudartana, I Wayan. 2016. Proses Pengadopsian System Of Rice Intensification (SRI) Oleh Anggota Subak Pacung di Desa Selat, Kecamatan Abiansemal, Kabupaten Badung (Skripsi). Bali: Fakultas Pertanian. Universitas Udayana.

Suyatna, 1987. Ciri-Ciri Kedinamisan Kelompok Sosial Tradisional di Bali dan Peranannya dalam Pembanguan. (Disertasi). Fakultas Pasca Sarjana. Institut Pertanian Bogor. 